\title{
Monitoring the Efficiency of Rhazya stricta L. Plants in Phytoremediation of Heavy Metal-Contaminated Soil
}

\author{
Ehab Azab ${ }^{1,2, *}$ and Ahmad K. Hegazy ${ }^{3}$ \\ 1 Biotechnology Department, Faculty of Science, Taif University, Taif 21974, Saudi Arabia \\ 2 Botany and Microbiology Department, Faculty of Science, Zagazig University, Zagazig 44519, Sharkia, Egypt \\ 3 Botany and Microbiology Department, Faculty of Science, Cairo University, Giza 12613, Egypt; \\ hegazy@sci.cu.edu.eg \\ * Correspondence: e.azab@tu.edu.sa; Tel.: +966-5307-43728
}

Received: 17 July 2020; Accepted: 18 August 2020; Published: 19 August 2020

check for updates

\begin{abstract}
Heavy metal-contaminated soil constitutes many environmental concerns. The toxic nature of heavy metals poses serious threats to human health and the ecosystem. Decontamination of the polluted soil by phytoremediation is of fundamental importance. Vegetation is an appealing and cost-effective green technology for the large-scale phytoremediation of polluted soils. In this paper, a greenhouse experiment was carried out to test the potential of Rhazya stricta as a heavy metal phytoremediator in polluted soil. Plants were grown for three months in pots filled with soils treated with the heavy metals $\mathrm{Cd}, \mathrm{Pb}, \mathrm{Cu}$, and $\mathrm{Zn}$ at rates of 10,50 , and $100 \mathrm{mg} / \mathrm{kg}$. The bioaccumulation factor (BCF) and translocation factor (TF) were calculated to detect the ability of $R$. stricta to accumulate and transfer heavy metals from soil to plant organs. The results showed that under increasing levels of soil pollution, the bioconcentration of $\mathrm{Cd}$ and $\mathrm{Zn}$ heavy metals showed the highest values in plant roots followed by leaves, whereas in the case of $\mathrm{Pb}$ and $\mathrm{Cu}$, roots showed the highest values followed by stems. Heavy metals accumulation was higher in roots than in stems and leaves. The BCF of $\mathrm{Zn}$ reached the highest values in roots and stems for $10 \mathrm{mg} / \mathrm{kg}$ soil treatment, followed by the BCFs of $\mathrm{Cd}, \mathrm{Cu}$, and $\mathrm{Pb}$. The TF for the different heavy metal pollutants' concentrations was less than unity, suggesting that the plants remediate pollutants by phytostabilization. The TF values ranged from higher to lower were in the order $\mathrm{Zn}>\mathrm{Cu}>\mathrm{Cd}>\mathrm{Pb}$. The rapid growth of $\mathrm{R}$. stricta and its tolerance of heavy metals, as well as its ability to absorb and accumulate metals within the plant, recommends its use in the phytoremediation of slightly polluted soils in arid lands by limiting the heavy metals transport.
\end{abstract}

Keywords: phytoremediation; Rhazya stricta; heavy metals; contaminated soil; arid lands

\section{Introduction}

Environmental contamination by heavy metals is becoming a critical problem of global concern. The toxic metals may remain in the environment for a long period and can eventually accumulate to levels that could cause major threats to human health [1].

Heavy metals are considered to be non-degradable inorganic pollutants, which are released to the environment from both human and natural activities, causing ecosystem disturbance [2]. Both volcanoes and parent material weathering are among the natural sources of heavy metal pollution [3]. Human activities, including mining, the use of fertilizers, pesticides and sludge as well as intensive asphaltic road construction across the natural landscape, are the main sources of heavy metal contamination of non-polluted soils, which in turn affects the food chain, leading to environmental and human health risks [4-7]. According to their importance to living organisms, heavy metals are classified into essential and nonessential metals. Among the essential metals are $\mathrm{Fe}, \mathrm{Ni}, \mathrm{Cu}, \mathrm{Mn}$, and $\mathrm{Zn}$, 
which have physiological functions in plant growth and development [8]. $\mathrm{Pb}, \mathrm{Cd}, \mathrm{As}$, and $\mathrm{Hg}$ are nonessential because they do not have significant roles in the physiological functions of plants [9]. Although phytoextraction requires a long time to clean up heavy metals from contaminated soil, its cost-effectiveness and low environmental impact outweigh the time factor $[9,10]$.

Many biological methods have been designed to improve the phytoremediation mechanisms utilized in reducing, removing or extracting heavy metals from the contaminated zones. Decontamination of the polluted soil by phytoremediation is considered as an effective method using plants to remediate the hazardous waste sites [11].

Phytoremediation is a green cost-effective eco-approach used in cleaning up soil and water from the chemical contaminations. As an essential method utilized in reducing the environmental pollution, an interest in phytoremediation has been growing rapidly in recent years [10,12-17]. As an emerging and sustainable technology that is cost-effective, solar-driven, passive and aesthetically acceptable, phytoremediation has become a sustainable technology for contaminant removal that can be used in different habitat types [16]. Chemical or physical techniques such as chemical washing and incineration are costly remediation methods that affect soil properties [4].

Identifying the most effective phytoremediator plant species that resist or accumulate chemical pollutants in soil, water, and air will support the use of green technology for the reclamation of polluted ecosystems in different zonobiomes.

Natural vegetation is playing an essential ecological role in the recovery of disturbed and contaminated land [18-21]. Recently, the use of vegetation has represented an innovative green technique for the in situ and ex situ phytoremediation of polluted soils. The vegetation accumulates heavy metals and other chemical pollutants and thereby reduces their risk to the environment $[5,22,23]$.

In some plant communities, Rhazya stricta Decne is considered a keystone species that determines the general appearance of the plant community and maintains local biodiversity through its impact on the abundance and type of other species as a critical component of the food web in many locations [24]. Populations of $R$. stricta shape the general appearance of the plant community by accumulating sand mounds that form mound-field landscapes. These create shelter for burrowing animals and are considered nutrient islands that sustain many different plants and animals in the ecosystem. As ecosystem engineers, keystone species can create and modify as well as maintain the landscape around them. They influence the occurrence of other organisms and help define the overall biodiversity of their habitat [25].

R. stricta is an efficacious medicinal plant used in herbal drugs to cure abundant ailments [26]. In spite of the medicinal value of $R$. stricta Decne, medicinal wild plants in arid lands are not collected at a large scale through industrialization because of their low biomass productivity but they are cultivated in agricultural lands for commercial use. Studying the heavy metal accumulation potential of $R$. stricta may result in a recommendation not to cultivate the species for medicinal purposes in heavy metal-polluted areas or areas watered with polluted water.

Phytoremediation of heavy metal-polluted soils using R. stricta plants, and their ability to absorb and accumulate heavy metals, have been investigated in various research topics. It was revealed that the accumulation factor for copper, cadmium, lead, and zinc was higher in roots of $R$. stricta compared with stems or leaves [27]. Moreover, $R$. stricta plants were suggested as an indicator for soil contamination, especially with $\mathrm{Cd}$ and $\mathrm{Pb}$ heavy metals [28]. $R$. stricta plants were also utilized to remove arsenic (As) from contaminated aqueous solutions [29]. Furthermore, R. stricta plant species were considered as resistant plants as these plants contain in their tissues amounts of heavy metals higher than those considered toxic for plants [30].

For some native plants such as $R$. stricta, A. Mexicana, C. colocynthis, C. italic, P. australis, C. laevigatus, and $\mathrm{C}$. procera, the bioaccumulation factor values of $\mathrm{Cd}, \mathrm{Cu}, \mathrm{Ni}$, and $\mathrm{Zn}$ were higher than the values of $\mathrm{Cr}, \mathrm{Co}, \mathrm{Fe}$, and $\mathrm{Pb}$ heavy metals [31]. Further, some wild plants such as R. stricta, L. shawii, $M$. parviflora, and P. australis plants were effective in phytoextraction of $\mathrm{Cd}$ and $\mathrm{Pb}$ heavy metals [32]. Some plant species such as R. stricta, E. cornigera, and C. colocynthis were suggested as bio-indicators 
and accumulators for contaminated soil [33]. In addition, some medicinal plants such as R. stricta, $C$. spinosa, P. harmala, and T. articulata were recommended to accumulate $\mathrm{Fe}, \mathrm{Ni}, \mathrm{Mn}, \mathrm{Zn}, \mathrm{Cu}, \mathrm{Cd}, \mathrm{Cr}$, and $\mathrm{Pb}$ heavy metals at different concentrations [34].

Further intensive studies on Rhazya stricta plants recommended their use in the phytoremediation of toxic heavy metals in the contaminated natural areas of many countries where they grow. The major goal of this study is to investigate the efficiency of Rhazya stricta L. plants in the phytoremediation of heavy metal-contaminated soil. The study was conducted as a pot experiment in an open greenhouse by including the usually accompanied contaminant heavy metals copper, zinc, cadmium, and lead.

\section{Results}

\subsection{Growth Rate and Resource Allocation}

The growth rate of $R$. stricta plants under different heavy metal treatments is illustrated in Figure 1. The obtained results showed that there is no significant difference at 10 and $50 \mathrm{mg} / \mathrm{kg}$ heavy metals concentration for both fresh and dry weight. For $100 \mathrm{mg} / \mathrm{kg}$ heavy metals concentration, a slight decrease in biomass compared with the control group was remarked (Figure 1a,b).
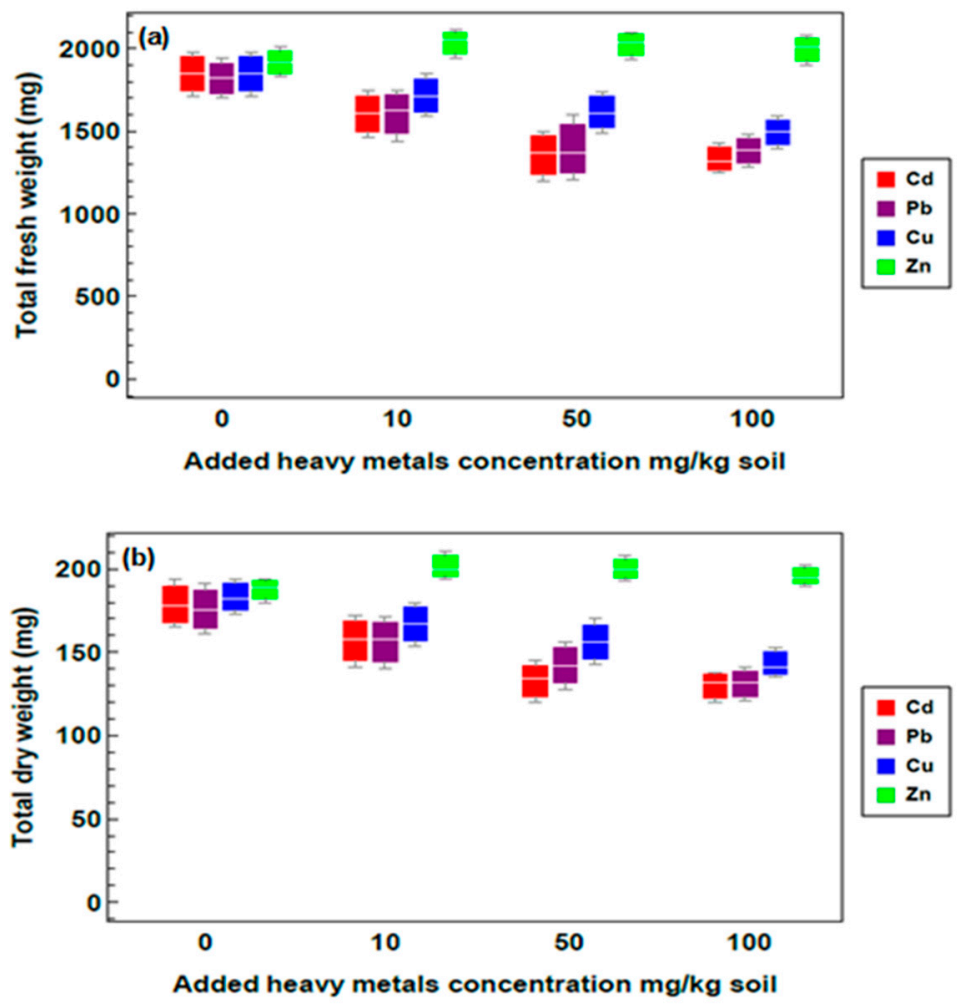

Figure 1. Growth rate of $R$. stricta plants exposed to different heavy metal treatments. (a) Fresh weight, and (b) dry weight of $R$. stricta plants samples under different treatments (means \pm standard errors $(n=5)$ for different heavy metal treatments).

Dry matter allocation of $R$. stricta plants under different heavy metal treatments across different plant organs was introduced in Figure 2. The results in this figure indicated that, the percentage of root dry weight ranged from $30 \%$ to $35 \%$ for control, while for $100 \mathrm{mg} / \mathrm{kg}$ soil heavy metal treatments it ranged from $30 \%$ to $33 \%$. This indicates that there is no significant change in the root dry weight even at $100 \mathrm{mg} / \mathrm{kg}$ heavy metal treatments. Since the plants were grown in the greenhouse, non-significant root growth was observed. The same pattern was also detected for stem and leaf as shown in Figure 2. Therefore, dry matter allocation in R. stricta plant organs was not affected by the applied levels of concentration of different heavy metals. 


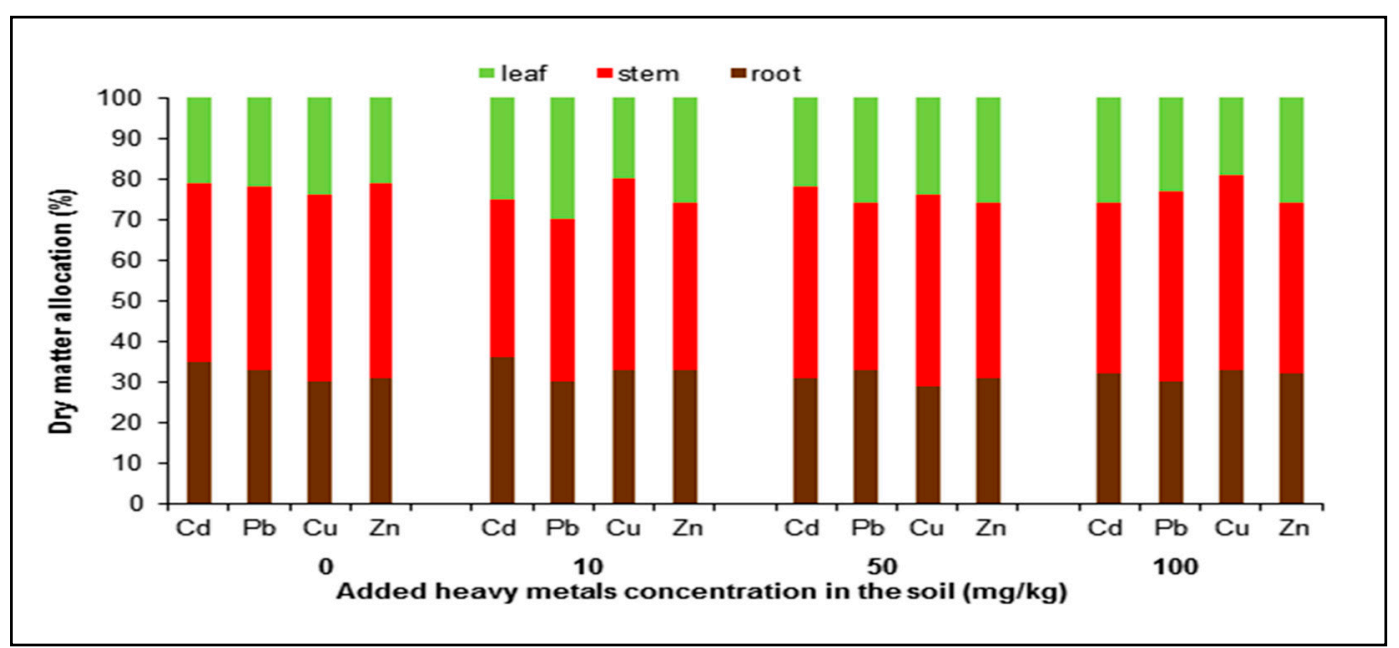

Figure 2. Dry matter allocation (\%) of $R$. stricta plants under different heavy metal treatments across different plant organs. Soil treated with different heavy metals $(\mathrm{Cd}, \mathrm{Pb}, \mathrm{Cu}$, and $\mathrm{Zn}$ ) concentrations 10 , 50 and $100 \mathrm{mg} / \mathrm{kg}$ soil in an open greenhouse.

\subsection{Concentration of Heavy Metals}

Heavy metals uptake by Rhazya stricta plants through the phytoremediation mechanism was observed as a clear increase in heavy metals concentration within different plant organs. For $\mathrm{Cd}$ heavy metal (Figure 3), the highest concentration value was $21.87 \mathrm{mg} / \mathrm{kg}$ in plant roots under the $100 \mathrm{mg} / \mathrm{kg} \mathrm{Cd}$ soil treatment, compared with the concentration in the roots of the control, at $7.01 \mathrm{mg} / \mathrm{kg}$. The highest concentration for leaves and stem were recorded in the $50 \mathrm{mg} / \mathrm{kg}$ soil treatment since they were 15.5 and $12.76 \mathrm{mg} / \mathrm{kg}$, respectively. Accumulated Cd in stem at $100 \mathrm{mg} / \mathrm{kg}$ treatment was much lower than in other treatments with a value of $2.87 \mathrm{mg} / \mathrm{kg}$. At $100 \mathrm{mg} / \mathrm{kg} \mathrm{Cd}$ concentration, a significant increase was remarked in root, whereas a significant decrease was remarked for stem and leaves.

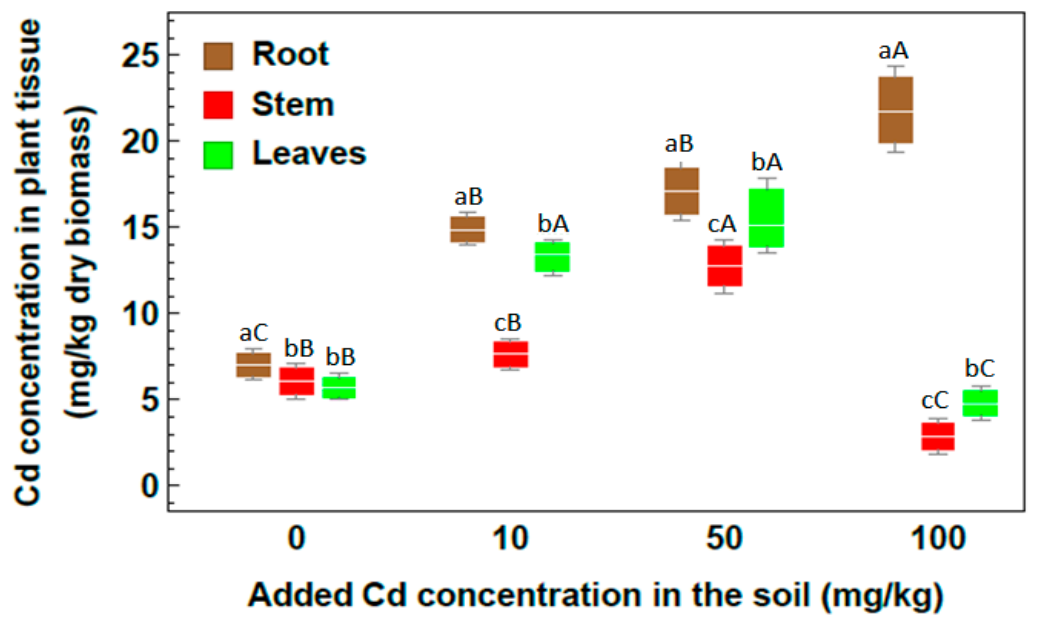

Figure 3. Concentration of Cd in plant organs of Rhazya stricta grown in soil treated with 10,50 and $100 \mathrm{mg} \mathrm{Cd} / \mathrm{kg}$ soil in an open greenhouse. Different lowercase letters indicate significant differences between plant parts for each soil metal concentration, and different capital letters indicate a significant difference between soil metal concentrations for each plant part $(p<0.05)$.

The $\mathrm{Pb}$ concentration in the $\mathrm{R}$. stricta organs was higher in all $\mathrm{Pb}$ soil treatments than in the control (Figure 4). The $\mathrm{Pb}$ concentration in the roots was significantly higher than that in the stem and leaves. The maximum $\mathrm{Pb}$ concentration was $56.20 \mathrm{mg} / \mathrm{kg}$ in the roots of plants grown in soils treated with $\mathrm{Pb}$ at $100 \mathrm{mg} / \mathrm{kg}$. The $\mathrm{Pb}$ concentration in the stem was higher than that in the leaves under all $\mathrm{Pb}$ 
treatments. The results illustrated that within $50 \mathrm{mg} / \mathrm{kg} \mathrm{Pb}$ concentration, $R$. stricta plants showed high efficiency for absorbing $\mathrm{Pb}$ heavy metal and transferring it to the aerial parts, whereas in $100 \mathrm{mg} / \mathrm{kg} \mathrm{Pb}$ concentration, the root of $R$. stricta showed the highest absorption rate and failed to transfer Pb heavy metal to the aerial parts.

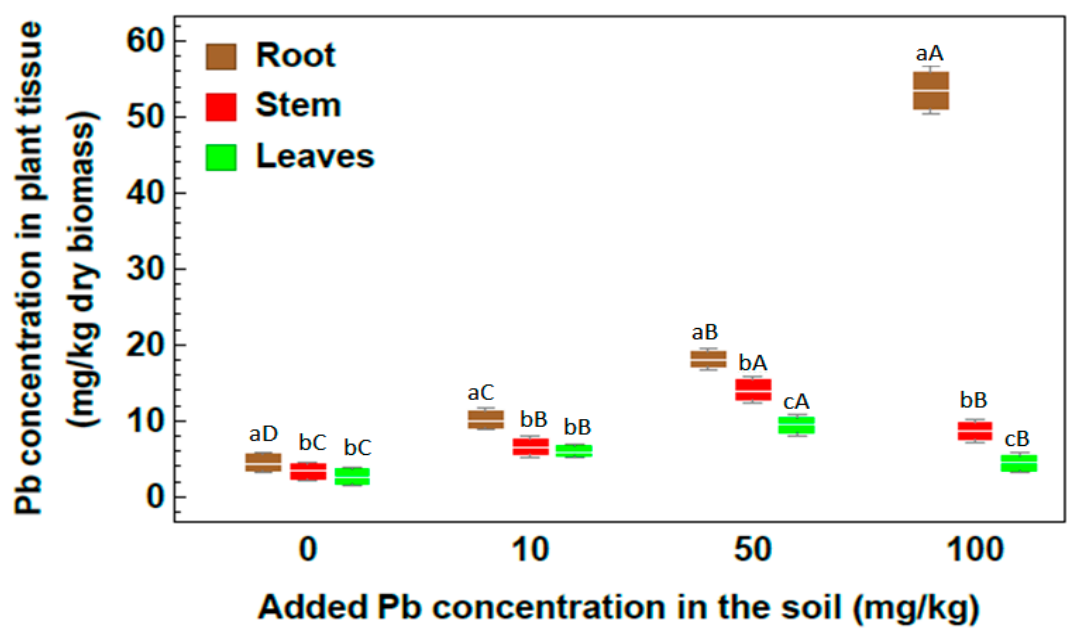

Figure 4. Concentration of $\mathrm{Pb}$ in plant organs of Rhazya stricta grown in soil treated with 10,50 and $100 \mathrm{mg} \mathrm{Pb} / \mathrm{kg}$ soil in an open greenhouse. Different lowercase letters indicate significant differences between plant parts for each soil metal concentration, and different capital letters indicate a significant difference between soil metal concentrations for each plant part $(p<0.05)$.

The concentration of $\mathrm{Cu}$ by R. stricta depended on the plant organ and the treatment level (Figure 5). The $\mathrm{Cu}$ concentration in the roots increased with the increasing level of $\mathrm{Cu}$ in the soil and reached $50.10 \mathrm{mg} / \mathrm{kg}$ in the $100 \mathrm{mg} / \mathrm{kg} \mathrm{Cu}$ soil treatment. In both the 50 and $100 \mathrm{mg} / \mathrm{kg}$ treatments, the Cu concentration in leaves was higher than that in the stem, while the bioaccumulation value in the stem was higher than that in leaves for plants grown in soil treated with $10 \mathrm{mg} / \mathrm{kg} \mathrm{Cu}$.

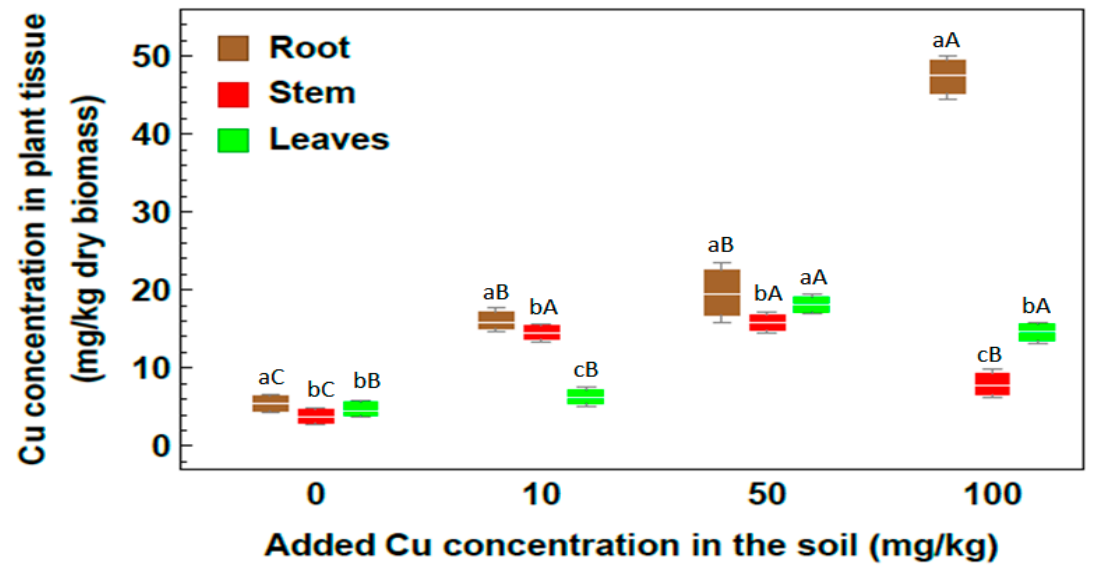

Figure 5. Concentration of $\mathrm{Cu}$ in plant organs of Rhazya stricta grown in soil treated with 10, 50 and $100 \mathrm{mg} \mathrm{Cu} / \mathrm{kg}$ soil in an open greenhouse. Different lowercase letters indicate significant differences between plant parts for each soil metal concentration, and different capital letters indicate a significant difference between soil metal concentrations for each plant part $(p<0.05)$.

Considering the concentration of $\mathrm{Zn}$ in $\mathrm{R}$. stricta (Figure 6), $\mathrm{Zn}$ bioaccumulation increased with increasing $\mathrm{Zn}$ content in the soil. By comparing the $\mathrm{Zn}$ concentrations for all considered treatments, the highest $\mathrm{Zn}$ concentration values were observed at $100 \mathrm{mg} \mathrm{Zn/kg}$. For $100 \mathrm{mg} \mathrm{Zn} / \mathrm{kg}$, the highest 
$\mathrm{Zn}$ concentration was recorded in roots with value $131.66 \mathrm{mg} / \mathrm{kg}$, followed by leaves with value $88.98 \mathrm{mg} / \mathrm{kg}$. This indicates that Rhazya stricta plants were successful in absorbing Zn heavy metal and transferring it to the aerial plant parts. Generally, for all considered treatments, $R$. stricta plants showed high efficiency in Zn heavy metal uptake and accumulation.

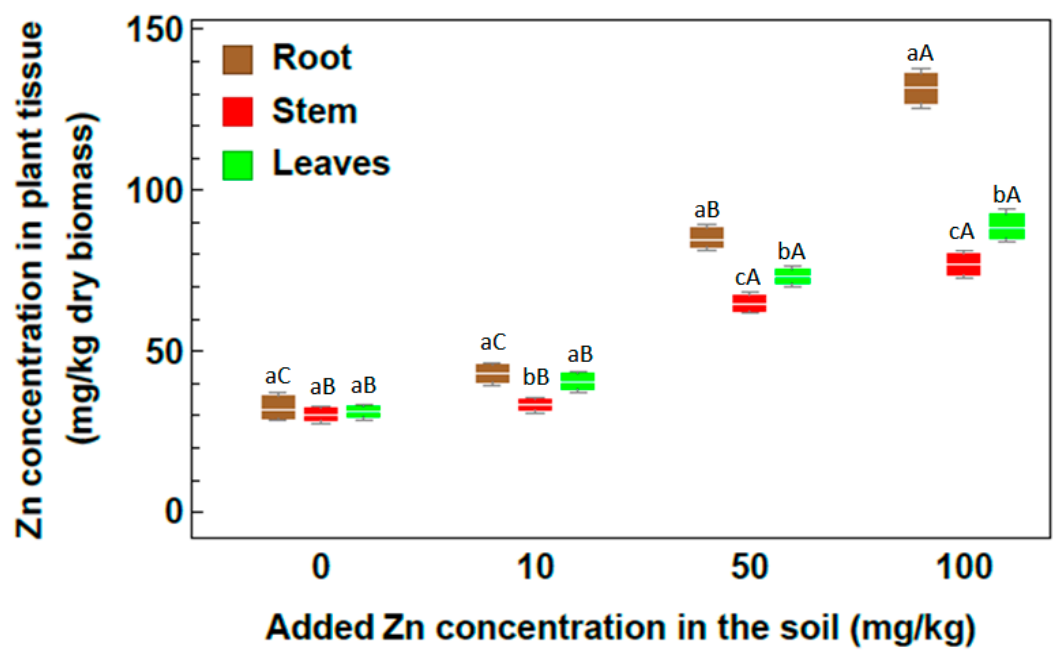

Figure 6. Concentration of $\mathrm{Zn}$ in plant organs of Rhazya stricta grown in soil treated with 10, 50 and $100 \mathrm{mg} \mathrm{Zn/kg} \mathrm{soil} \mathrm{in} \mathrm{an} \mathrm{open} \mathrm{greenhouse.} \mathrm{Different} \mathrm{lowercase} \mathrm{letters} \mathrm{indicate} \mathrm{significant} \mathrm{differences}$ between plant parts for each soil metal concentration, and different capital letters indicate a significant difference between soil metal concentrations for each plant part $(p<0.05)$.

Regarding the element distribution in plant organs, the concentrations of both essential and nonessential elements were significantly higher in root than in shoot, and essential elements such as $\mathrm{Zn}$ and $\mathrm{Cu}$ were efficiently trapped in roots; however, both root and shoot are considered as the main sites of metal accumulation.

\subsection{Correlation Analysis}

Correlation coefficients between heavy metal concentrations in soil and heavy metal concentrations in Rhazya stricta plant organs based on all treatments are listed in Table 1.

Table 1. Correlation coefficients $(r)$ between heavy metal concentrations in the soil and heavy metal concentrations in the plant organs.

\begin{tabular}{cccc}
\hline Metal & Root & Stem & Leaf \\
\hline $\mathrm{Cd}$ & 0.856 & -0.250 & -0.201 \\
$\mathrm{~Pb}$ & $0.988^{*}$ & 0.478 & 0.210 \\
$\mathrm{Cu}$ & $0.95^{*}$ & 0.576 & 0.117 \\
$\mathrm{Zn}$ & $0.996^{*}$ & $0.968^{*}$ & $0.964^{*}$ \\
\hline
\end{tabular}

${ }^{*}$ Correlations are significant at the 0.05 level $(n=5)$.

For Zn treatments, significant positive correlation between $\mathrm{Zn}$ concentrations in soil and $\mathrm{Zn}$ concentrations in root, stem and leaf $(r=0.996,0.968$, and 0.964 , respectively) were observed. For $\mathrm{Pb}$ and $\mathrm{Cu}$, a significant positive correlation was detected for root only with values $(r=0.988$ and 0.95 , respectively). Under different $\mathrm{Cd}$ treatments, negative correlations were detected $(r=-0.25,-0.20)$ for stem and leaf, respectively. 


\subsection{Bioconcentration and Translocation Factors}

The calculated bioconcentration factor (BCF) demonstrated that plants grown under the $10 \mathrm{mg} / \mathrm{kg}$ Cd soil treatment had high BCF values (Figure 7a); the BCF values in roots and leaves exceeded unity and were 1.30 and 1.14, respectively. In contrast, plants grown in soil Cd treatments of 50 and $100 \mathrm{mg} / \mathrm{kg}$ had a lower ability to concentrate $\mathrm{Cd}$ in their organs.
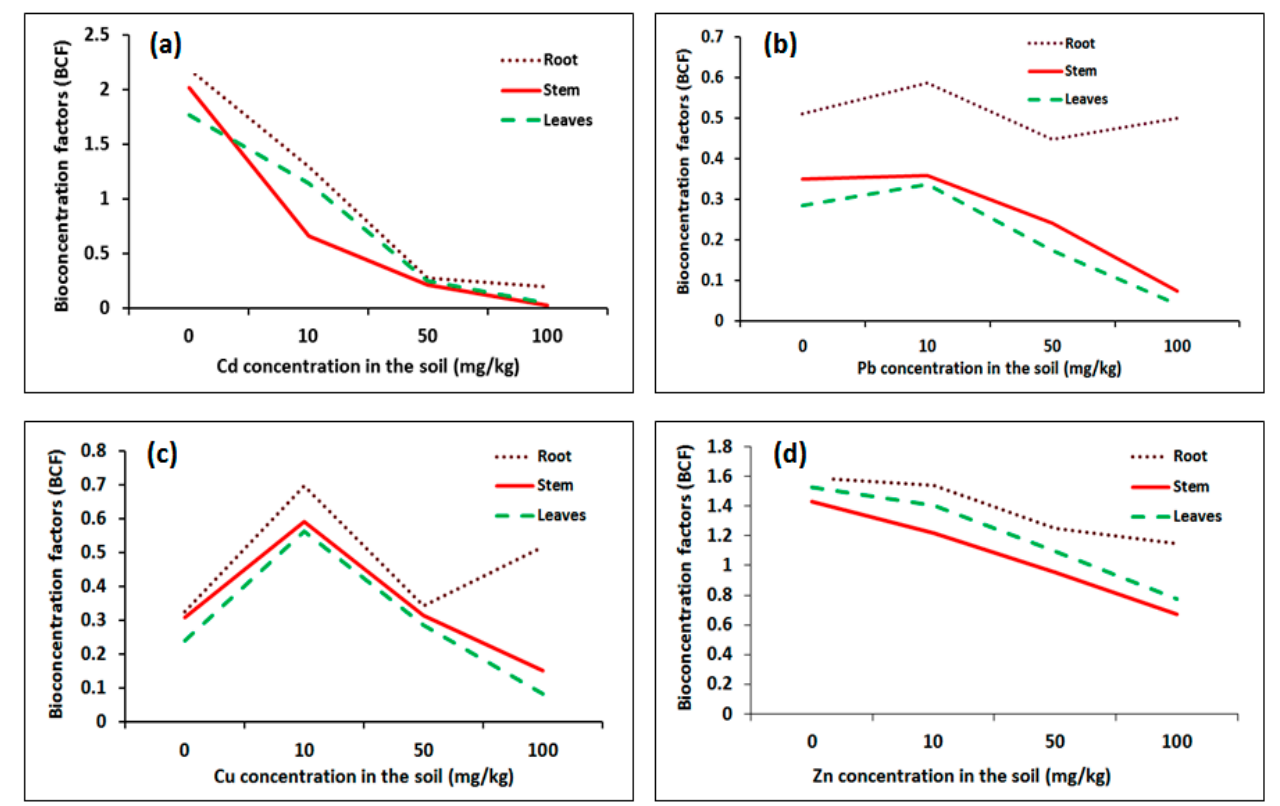

Figure 7. Bioconcentration factor (BCF) of Rhazya stricta plant organs grown in soil treated with heavy metal treatments of 10,50 and $100 \mathrm{mg} / \mathrm{kg}$ soil in an open greenhouse. (a) BCF of Rhazya stricta plant organs in soil treated with Cd, (b) BCF of Rhazya stricta plant organs in soil treated with $\mathrm{Pb},(\mathbf{c}) \mathrm{BCF}$ of Rhazya stricta plant organs in soil treated with $\mathrm{Cu},(\mathrm{d}) \mathrm{BCF}$ of Rhazya stricta plant organs in soil treated with $\mathrm{Zn}$.

The BCF of $\mathrm{Pb}$ Figure $7 \mathrm{~b}$ had higher values for $10 \mathrm{mg} / \mathrm{kg} \mathrm{Pb}$ soil treatment and reached 0.57, 0.36 and 0.34 in roots, stems and leaves, respectively. For the $100 \mathrm{mg} / \mathrm{kg} \mathrm{Pb}$ treatment, the BCF in plant roots was 0.5 .

For $\mathrm{Cu}$, the $\mathrm{BCF}$ values for different plant organs under $10 \mathrm{mg} / \mathrm{kg}$ were higher than the BCF values recorded in the other treatments (Figure 7c), whereas for $50 \mathrm{mg} / \mathrm{kg} \mathrm{Cu}$ treatment, the BCF values were reduced by $50 \%$ compared to the results of $10 \mathrm{mg} / \mathrm{kg}$. The plant roots showed BCF values of 0.52 under $100 \mathrm{mg} / \mathrm{kg} \mathrm{Cu}$ treatment, which was higher than the values for stems and leaves.

The plants grown in different soil $\mathrm{Zn}$ treatments (Figure 7d) showed BCF values of more than one for plants grown in the $10, \mathrm{mg} / \mathrm{kg}$ and $50 \mathrm{mg} / \mathrm{gr} \mathrm{Zn}$ treatments. The BCF values for $10 \mathrm{mg} / \mathrm{kg}$ $\mathrm{Zn}$ treatments were 1.54, 1.22 and 1.41 in the roots, stems and leaves, respectively, and for $50 \mathrm{mg} / \mathrm{kg}$, the BCF values were 1.25, 1.02 and 1.1 in the roots, stems and leaves, respectively.

For all treatments, the highest BCF value was found in the root at $10 \mathrm{mg} / \mathrm{kg} \mathrm{Zn}$ metal treatment, which was 1.538 , followed by those of $\mathrm{Cd}, \mathrm{Cu}$ and $\mathrm{Pb}$, with values of $1.30,0.70$ and 0.58 , respectively. For stems, the BCF of $\mathrm{Zn}$ reached 1.22 under $10 \mathrm{mg} / \mathrm{kg}$ treatment, followed by those of $\mathrm{Cd}, \mathrm{Cu}$ and $\mathrm{Pb}$ with values of $0.66,0.59$ and 0.36 , respectively. In the case of plant leaves, the same trend as stem was observed. The order of heavy metals uptake from soil by $R$. stricta from higher to lower values was $\mathrm{Zn}>\mathrm{Cd}>\mathrm{Cu}>\mathrm{Pb}$.

The translocation factor (TF) of the different heavy metals was less than unity. High TF values were recorded in the control, $10 \mathrm{mg} / \mathrm{kg}$ and $50 \mathrm{mg} / \mathrm{kg}$ soil treatments. In contrast, low TF values were measured in plants grown under $100 \mathrm{mg} / \mathrm{kg}$ treatment (Table 2). Generally, R. stricta plants show high metal bioaccumulation and translocation from roots to stems and leaves. 
Table 2. Translocation factors (TF) of $\mathrm{Cd}, \mathrm{Pb}, \mathrm{Cu}$ and $\mathrm{Zn}$ in $\mathrm{R}$. stricta plants grown in soils treated with heavy metal concentrations of 10,50 and $100 \mathrm{mg} / \mathrm{kg}$ and natural soil as a control.

\begin{tabular}{ccccccccc}
\hline \multirow{2}{*}{ Metal Conc. in Soil } & \multicolumn{7}{c}{ Translocation Factor in Plant Shoots } \\
\cline { 2 - 9 } & \multicolumn{2}{c}{ Cd } & \multicolumn{2}{c}{ Pb } & \multicolumn{2}{c}{ Cu } & \multicolumn{2}{c}{ Zn } \\
\cline { 2 - 9 } & TF Stem & TF Leaves & TF Stem & TF Leaves & TF Stem & TF Leaves & TF Stem & TF Leaves \\
\hline 0 & $0.92^{\mathrm{a}}$ & $0.81^{\mathrm{a}}$ & $0.69^{\mathrm{a}}$ & $0.56^{\mathrm{a}}$ & $0.74^{\mathrm{a}}$ & $0.95^{\mathrm{a}}$ & $0.90^{\mathrm{a}}$ & $0.96^{\mathrm{a}}$ \\
10 & $0.51^{\mathrm{b}}$ & $0.88^{\mathrm{a}}$ & $0.61^{\mathrm{a}}$ & $0.57^{\mathrm{a}}$ & $0.81^{\mathrm{a}}$ & $0.35^{\mathrm{b}}$ & $0.79^{\mathrm{b}}$ & $0.92^{\mathrm{a}}$ \\
50 & $0.79^{\mathrm{a}}$ & $0.91^{\mathrm{a}}$ & $0.74^{\mathrm{a}}$ & $0.53^{\mathrm{b}}$ & $0.83^{\mathrm{a}}$ & $0.92^{\mathrm{a}}$ & $0.76^{\mathrm{b}}$ & $0.88^{\mathrm{a}}$ \\
100 & $0.13^{\mathrm{c}}$ & $0.23^{\mathrm{b}}$ & $0.15^{\mathrm{b}}$ & $0.08^{\mathrm{c}}$ & $0.16^{\mathrm{b}}$ & $0.29^{\mathrm{b}}$ & $0.59^{\mathrm{c}}$ & $0.68^{\mathrm{b}}$ \\
L.S.D & 0.15 & 0.21 & 0.12 & 0.02 & 0.27 & 0.12 & 0.01 & 0.12 \\
\hline
\end{tabular}

The different letters refer to significant differences at $p<0.05$.

\section{Discussion}

The use of vegetation and associated microflora is becoming an important green technology for the in situ remediation of soils polluted with different heavy metals without the need of other chemical or artificial techniques, which have proved to be costly and ineffective for remediation at a large scale $[5,23,35]$. This is due to the role of vegetation, particularly of keystone species, in conserving the soil from erosion and preventing the leaching of pollutants to the underground water and the surrounding ecosystems.

For morphological features, the obtained results indicated the ability of $R$. stricta plants to grow in heavy metal-contaminated soil without significant morphological changes. This might be due to the ability of these plants to remove the heavy metals from contaminated soil without remarkable effect on their growth. These results illustrated that $R$. stricta plants can accumulate heavy metals while having normal morphological appearance. Therefore, they should be checked for contaminant load before processing them for clinical purposes. This suggestion is consistent with the suggestion introduced by Shah et al. [34] who illustrated that some medicinal plants, including R. stricta, should be checked for contaminant load before processing them for pharmaceutical purposes or for local human consumption. The non-significant root growth observed in this study might be due to the root confinement within a limited volume of the minipots with ample and regular water irrigation for the plants grown in the greenhouse [36].

The results for $\mathrm{Cd}$ heavy metal clarify that $50 \mathrm{mg} / \mathrm{kg}$ treatments showed the highest efficiency for bioaccumulation of heavy metal by root and transferred it to the aerial parts. Studies on lettuce plants by [37] on the bioaccumulation of Cd showed similar results to those obtained for R. stricta. Lettuce plants represented a good example for $\mathrm{Cd}$ absorption from the soil by root, subsequently translocated via xylem vessels to leaves.

Lead is naturally presented in in the earth's crust at concentrations of $8-20 \mathrm{mg} / \mathrm{kg}$ soil [38]. The phytoremediation mechanism would be suggested to remediate the elevated lead concentrations from contaminated soil. The study of [39] demonstrated the ability of Cynodon dactylon to accumulate $\mathrm{Pb}$, where the shoot-root ratio, which helps to verify the translocation of heavy metals through the plant, showed that the amount of accumulated $\mathrm{Pb}$ was higher in roots and subterranean rhizomes than in aerial shoots. The same results were obtained with $R$. stricta; the plants showed a high ability to accumulate $\mathrm{Pb}$ within the roots even at a high heavy metal concentration of $100 \mathrm{mg} / \mathrm{kg}$ in the soil. The $\mathrm{Pb}$ content in the plant roots increased with the increased $\mathrm{Pb}$ levels in soil, as the dependence of the $\mathrm{Pb}$ content on soil characteristics may control heavy metal availability for plants [39,40].

The normal concentration range of $\mathrm{Cu}$ in plants is from $5-20 \mathrm{mg} / \mathrm{kg}$ [41]. Obtained results for $\mathrm{Cu}$ concentration illustrate that by increasing the level of $\mathrm{Cu}$ in soil, an increase in $\mathrm{Cu}$ concentration occurs in the root. Similar results were obtained by Ibrahim et al. [32], who reported that the amount of $\mathrm{Cu}$ accumulated in the roots of Lycium shawii, Phragmites australis, and R. stricta reached 2 to 4.5 times that accumulated in the shoot. The results of this study showed also that leaves of $R$. stricta accumulate $\mathrm{Cu}$ more than stem in both 50 and $100 \mathrm{mg} / \mathrm{kg}$ treatments. These results agree with the results given in [42], 
which stated that the shoot of Convolvulus arvensis accumulated Cu to more than $560 \mathrm{mg} / \mathrm{kg}$ dry plant tissue in heavy metal-contaminated sites. The same was demonstrated by Khattak et al. [33], who found that the highest $\mathrm{Cu}$ concentration was detected within $R$. stricta plants compared to C. colocynthis and E. cornigera plants.

Zinc is a micronutrient element that helps in the formation of a large number of different enzymes and plays an important role in regulatory and catalytic functions. Zn has a significant role in pollen formation, DNA synthesis and also enhances the antioxidant enzymes and photosynthesis within plant tissues [43]. Zn concentrations in the unpolluted soil depend on geology and specific site conditions. $\mathrm{Zn}$ toxic effects occur at concentrations greater than $100 \mathrm{mg} / \mathrm{kg}$ soil as illustrated by Mertens and Smolders [44]. To discuss low or moderate pollution levels, the concentrations 10, 50 and $100 \mathrm{mg} / \mathrm{kg}$ of $\mathrm{Zn}$ heavy metal were added to soil. Zn hyperaccumulator plants accumulate more than $10 \mathrm{mg} / \mathrm{g}$ dry weight in the aerial parts when growing in their natural environment [45]. Results obtained by [46] for Thlaspi caerulescens plants, reported high $\mathrm{Zn}$ accumulation in plant tissues in soil treated with up to $100 \mathrm{mg} / \mathrm{kg}$ soil. The same results were obtained in the present study, since it was clear that $R$. stricta plants showed high efficiency to absorb Zn heavy metal and transfer it to the aerial parts with all treatments. In spite of the harmful effect of zinc heavy metal on plants, it is less toxic compared to several other heavy metals and is relatively harmless $[47,48]$. So it was clear that with all treatments of $\mathrm{Zn}$ concentration, $R$. stricta plants showed high efficiency for absorbing Zn heavy metal and transferring it to the aerial parts.

By increasing heavy metal concentrations in the soil, the rate of heavy metal uptake by the root, and the bioaccumulation as well as the translocation in the plant, increased. This increase exceeds the normal levels of these metals in plants. Such results are in agreement with the findings of $[49,50]$ in other species that demonstrated their ability to remediate rhizosphere soils due to the high uptake and bioaccumulation of heavy metals in their tissues.

In this study, within all treatments of $\mathrm{Zn}, \mathrm{Cu}, \mathrm{Pb}$, and $\mathrm{Cd}$ metals, root showed the highest metal concentrations. Similar results were illustrated by Badr et al. [30], who reported that after testing several native plants, including the R. stricta plant, for polluted metal phytoextraction, all plants accumulated high concentrations of toxic pollutants within their root.

In this study, at $100 \mathrm{mg} / \mathrm{kg} \mathrm{Cd}, \mathrm{Pb}$, and $\mathrm{Cu}$ heavy metals concentration, a significant increase in heavy metals concentration was remarked in the root, whereas a significant decrease was remarked for stem and leaves. This might be due to the high concentration of heavy metals in the root, which caused severe physiological damage the root of the plant and reduced its ability to translocate heavy metals to aerial parts of the plant. Therefore, a significant decrease in heavy metal concentrations was remarked for stem and leaves at $100 \mathrm{mg} / \mathrm{kg}$ soil treatment [51]. Al-qahtani [31] studied the efficiency of seven native plants, including the $R$. stricta plant, for bioaccumulation of eight heavy metals. The results showed that all selected plants had efficiency in accumulating and translocating several heavy metals including $\mathrm{Cd}, \mathrm{Pb}, \mathrm{Cu}$, and $\mathrm{Zn}$, with different levels. The P. australis and C. laevigatus plants showed higher capability for heavy metals accumulation than other studied native plants including $R$. stricta.

Bioconcentration factor (BCF) and translocation factor (TF) are parameters that can be used to estimate plant phytoremediation potential [52]. Based on the metal availability in soil and its uptake by plants, the bioaccumulation and translocation factor values indicate the ability of plants to accumulate and transfer heavy metals within their tissues [53-56]. The translocation of the accumulated heavy metals from the roots to the shoots starts after the roots lose their ability to phytostabilize or to store the heavy metals [57]. The values of bioconcentration factor (BCF) given by Al-qahtani [31] were higher than the values recorded in this study; this may be due to the fact that the Al-qahtani [31] study was done in the field with mature plants, while our experiment was done in greenhouse for plants germinated only for three months.

The efficiency of heavy metal translocation from root to shoot can be detected according to TF values [58]. Effective heavy metal transfer was suggested at TF values greater than one, whereas at TF 
values of less than one, these types of plants could accumulate metals in roots and rhizomes more than in shoots or leaves, which suggested ineffective metal transfer [55].

In this study, the results for $R$. stricta demonstrated that the bioconcentration factor (BCF) of $\mathrm{Zn}$ and $\mathrm{Cd}$ heavy metals in root and shoot indicates the plant's capacity to accumulate these metals. The translocation factor (TF) values of the four considered heavy metals, however, were near to one, which suggests that the plant remediates heavy metals by phytostabilization through concentrating the metals in the root. Both $\mathrm{Zn}$ and $\mathrm{Cu}$ showed the highest (TF) values. The same pattern for translocation factor of $R$. stricta was obtained by Al-Farraj et al. [27] who demonstrated that Zinc heavy metal attained the highest values of translocation factor (TF) compared to $\mathrm{Cd}, \mathrm{Cu}$, and $\mathrm{Pb}$ heavy metals. Phytostabilization of heavy metals limits its transport as well as keeping animals from toxic species ingestion, and consequently prevents transmission across the food chain.

\section{Materials and Methods}

\subsection{Study Species}

Rhazya stricta Decne. (Apocynaceae) is a native evergreen perennial herb that is widely distributed in Saudi Arabia. Plant populations and communities dominated by R. stricta are found in depressions and overgrazed sandy flats with silty and sandy soils [24]. As an unpalatable species for grazing domestic animals, the species dominates overgrazed or deteriorated grazing lands and shapes the physiognomy of the landscape as a keystone species. Mature seeds were collected from plant populations growing naturally in sand flats along Taif and Makkah roads, Saudi Arabia and used in pot experiments. Filled seeds were collected at the fruit dehiscence/seed dispersal stage. The seeds were collected from 50 individual plants selected randomly in one population covering approximately $2 \mathrm{~km}^{2}$ of land area.

\subsection{Pot Experiment}

$R$. stricta seeds were germinated and grown for three weeks in untreated soil in minipot seedling trays. The three-week-old plants were transplanted into plastic pots of $22 \mathrm{~cm}$ in diameter and $25 \mathrm{~cm}$ depth. Healthy plants of similar height were selected for transplantation. The pots contained soil collected from the plants' natural habitat. The soil was sandy-loamy with a slightly alkaline $\mathrm{pH} 7.3$, a low organic matter content $(0.48 \%)$, a total carbonate concentration of $19.3 \%$, and electric conductivity of $986 \mathrm{mhos} / \mathrm{cm}$. The concentrations of the different heavy metals in the natural (control) soil were $\mathrm{Cd}$ $3.2 \mathrm{mg} / \mathrm{kg}$ soil, $\mathrm{Pb} 8.1 \mathrm{mg} / \mathrm{kg}$ soil, $\mathrm{Cu} 17.1 \mathrm{mg} / \mathrm{kg}$, and $\mathrm{Zn} 20.5 \mathrm{mg} / \mathrm{kg}$.

The experiment was conducted in an open greenhouse starting in mid-February and terminating by the end of May. During the experimental period, the average maximum temperature was $28^{\circ} \mathrm{C}$, ranging from $22{ }^{\circ} \mathrm{C}$ to $32{ }^{\circ} \mathrm{C}$, and the average minimum temperature was $15^{\circ} \mathrm{C}$, ranging from $14{ }^{\circ} \mathrm{C}$ to $18{ }^{\circ} \mathrm{C}$. Plants were watered regularly to the maximum $100 \%$ field capacity, which required watering every $2-3$ days.

For soil treatments, the pots were divided into groups. Five pots were considered with individual plants, as five replicates for each group. The first group was for the control without heavy metals. The other groups were for $\mathrm{Cd}, \mathrm{Pb}, \mathrm{Cu}$, and $\mathrm{Zn}$ treatments as five replicates for each considered concentration. For the heavy metal treatments, $\mathrm{Cd}$ was applied as $\mathrm{CdCl}_{2} \cdot 2 \frac{1}{2} \mathrm{H}_{2} \mathrm{O}, \mathrm{Pb}$ was applied as $\mathrm{Pb}\left(\mathrm{NO}_{3}\right)_{2}$, $\mathrm{Cu}$ was applied as $\mathrm{CuSO}_{4} \cdot 5 \mathrm{H}_{2} \mathrm{O}$, and $\mathrm{Zn}$ was applied as $\mathrm{ZnSO}_{4} \cdot 7 \mathrm{H}_{2} \mathrm{O}$.

To overcome the potential stress of heavy metal treatments at the seedling stage of plant growth, R. stricta seeds were germinated and grown for three weeks $[59,60]$ in untreated soil in minipot seedling trays. The three-week-old plants were transplanted into plastic pots of $22 \mathrm{~cm}$ in diameter and $25 \mathrm{~cm}$ depth. Since high concentrations of toxic heavy metals affected seedling germination [61-64], selected heavy metals were mixed in the soil at rates of 10,50 , and $100 \mathrm{mg} / \mathrm{kg}$ soil $[63,65,66]$. The considered heavy metal concentrations are also appropriate for the pollution range in the considered area. 
After the termination of the experiments, the individual plants in each pot were harvested and separated into their corresponding organs: roots, stems and leaves. The separated plant materials were washed with tap water followed by distilled water to remove dust and soil particles. The material was oven dried at $80^{\circ} \mathrm{C}$ for $48 \mathrm{~h}$ to a constant weight, ground into a fine powder and kept dry in paper bags in a desiccator for subsequent heavy metal analysis.

\subsection{Growth Rate}

For fresh and dry weight of $R$. stricta plants, three month grown plants at different heavy metal concentrations were harvested. The plants were washed with tap water followed by distilled water to determine the total fresh weight, and then plants were oven dried at $80^{\circ} \mathrm{C}$ for $48 \mathrm{~h}$ to a constant weight to detect the total dry weight. Dried samples were separated into their corresponding organs: roots, stems and leaves, then percentages of resources allocated across different organs were calculated.

\subsection{Heavy Metal Analysis}

The heavy metal content was determined in $0.5 \mathrm{~g}$ plant powder after digestion in $65 \%$ concentrated $\mathrm{HNO}_{3}$ and $2 \mathrm{~mL} \mathrm{HClO}_{4}$ following the procedure described by [67]. The heavy metal concentration was measured spectrophotometrically by atomic absorption (Thermo Scientific model ice 3000 SERIES AA) under the specific conditions shown in Table 3.

Table 3. Conditions for the measurement of heavy metal concentrations by atomic absorption.

\begin{tabular}{ccccc}
\hline Heavy Metal & Lamp Current $(\mathbf{m A})$ & Fuel & Support & Wavelength $(\mathbf{n m})$ \\
\hline Cadmium & 5 & Acetylene & Air & 228.8 \\
Lead & 10 & Acetylene & Air & 217 \\
Copper & 5 & Acetylene & Air & 324.8 \\
Zinc & 10 & Acetylene & Air & 213.9 \\
\hline
\end{tabular}

\subsection{Calculation of Bioconcentration and Translocation Factors}

The bioconcentration factor (BCF), a dimensionless factor, was calculated as the ratio of a given metal concentration in the plant tissues at harvest $(\mathrm{mg} / \mathrm{kg}$ dry weight) to the concentration of the metal in the soil medium according to the following equation [68].

$$
B C F=\frac{C_{\text {harvested tissue }}}{C_{\text {soil }}}
$$

where $C_{\text {harvested tissue }}$ is the metal concentration in the plant tissues (roots, stems or leaves) and $C_{\text {soil }}$ is the metal concentration in the soil.

Some plants showed an ability to translocate absorbed heavy metals from the root to the shoot system, and the ratio of the concentration of a heavy metal in plant shoots and its concentration in roots is defined as the translocation factor (TF).

The translocation factor (TF) was calculated as (shoot concentration/root concentration) $\mathrm{mg} / \mathrm{kg}$ dry weight [69].

$$
T F=\frac{C_{\text {Shoot }}}{C_{\text {root }}}
$$

where $C_{\text {shoot }}$ is the metal concentration in the plant tissues (stems or leaves) and $C_{\text {root }}$ is the metal concentration in the plant root. The TF is a dimensionless factor; a higher ratio implies higher translocation capability.

\subsection{Statistical Analysis}

Each experiment was conducted with five replicates. The results are shown as the mean \pm standard deviation. The experimental data were analyzed using the SPSS-22 statistical software package for 
PC. The heavy metal concentrations in the control and experimental treatments were compared using Student's $t$ test. To test the difference in heavy metal concentrations between different samples, the data were checked for normality and homogeneity and analyzed by two-way ANOVA using Fisher's post hoc test comparison method. To check the data normality and homogeneity, Levene's test of equality of error variances was applied to test the homogeneity and the Kolmogorov-Smirnov test was used to test the normality. The differences between samples were considered statistically significant at $p<0.05$. The correlation coefficient $(r)$ of the various metals with the concentration in the plants was calculated using Pearson's regression equation between metal concentration in soil and metal concentration in respective plant organ based on all treatments for the particular metal $[5,22,23]$.

\section{Conclusions}

The heavy metal concentration in the roots of $R$. stricta was higher than that in stems and leaves under the tested $\mathrm{Cd}, \mathrm{Pb}, \mathrm{Cu}$ and $\mathrm{Zn}$ soil treatments. This may be due to the increase in the heavy metal concentration in the soil leading to an increase in the bioaccumulation in roots. The phytoremediation ability of $R$. stricta prevents the mobility of the heavy metals in the soil to the surrounding areas, which suggests that this keystone species is a potential phytoremediator for lightly polluted soils. The bioaccumulation of heavy metals by $R$. stricta, including its ability to absorb and accumulate heavy metals, indicates that this species is a candidate for large-scale in situ phytoremediation of lightly polluted soils in arid regions. Further field studies are required to assess the phytoextraction, phytostabilization and rhizofiltration behavior of this species in natural habitats, as these are useful strategies in the remediation of heavy metal-polluted soils in plant communities in arid lands.

Author Contributions: E.A. and A.K.H. contributed equally in the paper conceptualization, methodology, investigation, and writing - review and editing. E.A. was responsible for the laboratory analysis of plant materials. All authors have read and agreed to the published version of the manuscript.

Funding: This research received no external funding.

Acknowledgments: This work was carried out using the facilities and materials of the biotechnology laboratory in the Department of Biotechnology, Taif University and the Ecology Laboratory in the Botany and Microbiology Department, Faculty of Science, Cairo University.

Conflicts of Interest: The authors declare no conflict of interest.

\section{References}

1. Xu, J.; Liu, C.; Hsu, P.-C.; Zhao, J.; Wu, T.; Tang, J.; Liu, K.; Cui, Y. Remediation of heavy metal contaminated soil by asymmetrical alternating current electrochemistry. Nat. Commun. 2019, 10, 2440. [CrossRef] [PubMed]

2. Tchounwou, P.B.; Yedjou, C.G.; Patlolla, A.K.; Sutton, D.J. Heavy metal toxicity and the environment. Exp. Suppl. 2012, 101, 133-164. [CrossRef]

3. Li, C.; Zhou, K.; Qin, W.; Tian, C.; Qi, M.; Yan, X.; Han, W. A review on heavy metals contamination in soil: Effects, sources, and remediation techniques. Soil Sediment Contam. Int. J. 2019, 28, 380-394. [CrossRef]

4. Ying, G.-G. Chapter 14 remediation and mitigation strategies. In Integrated Analytical Approaches for Pesticide Management; Maestroni, B., Cannavan, A., Eds.; Academic Press: Cambridge, MA, USA, 2018. [CrossRef]

5. Mahar, A.; Wang, P.; Ali, A.; Awasthi, M.K.; Lahori, A.H.; Wang, Q.; Li, R.; Zhang, Z. Challenges and opportunities in the phytoremediation of heavy metals contaminated soils: A review. Ecotoxicol. Environ. Saf. 2016, 126, 111-121. [CrossRef]

6. Roy, M.; McDonald, L.M. Metal uptake in plants and health risk assessments in metal-contaminated smelter soils. Land Degrad. Dev. 2013, 26, 785-792. [CrossRef]

7. Khan, S.; Cao, Q.; Zheng, Y.M.; Huang, Y.Z.; Zhu, Y.G. Health risks of heavy metals in contaminated soils and food crops irrigated with wastewater in Beijing, China. Environ. Pollut. 2008, 152, 686-692. [CrossRef]

8. Gohre, V.; Paszkowski, U. Contribution of the arbuscular mycorrhizal symbiosis to heavy metal phytoremediation. Planta 2006, 223, 1115-1122. [CrossRef] 
9. Peng, K.J.; Luo, C.L.; Chen, Y.H.; Wang, G.P.; Li, X.D.; Shen, Z.G. Cadmium and other metal uptake by Lobelia chinensis and Solanum nigrum from contaminated soils. Bull. Environ. Contam. Toxicol. 2009, 83, 260-264. [CrossRef]

10. Hegazy, A.K.; Emam, M.H.; Lovett-Doust, L.; Azab, E.; El-Khatib, A.A. Response of duckweed to lead exposure: Phytomining, bioindicators and bioremediation. Desalin. Water Treat. 2017, 70, 227-234. [CrossRef]

11. Gratão, P.L.; Prasad, M.N.V.; Cardoso, P.F.; Lea, P.J.; Azevedo, R.A. Phytoremediation: Green technology for the clean up of toxic metals in the environment. Braz. J. Plant Physiol. 2005, 17, 53-64. [CrossRef]

12. Azab, E.; Kebeish, R.; Hegazy, A.K. Expression of the human gene CYP1A2 enhances tolerance and detoxification of the phenylurea herbicide linuron in Arabidopsis thaliana plants and Escherichia coli. Environ. Pollut. 2018, 238, 281-290. [CrossRef]

13. Azab, E.; Hegazy, A.K.; El-Sharnouby, M.E.; Abd Elsalam, H.E. Phytoremediation of the organic Xenobiotic simazine by p450-1a2 transgenic Arabidopsis thaliana plants. Int. J. Phytoremediat. 2016, 18, 738-746. [CrossRef] [PubMed]

14. Moubasher, H.A.; Hegazy, A.K.; Mohamed, N.H.; Moustafa, Y.M.; Kabiel, H.F.; Hamad, A.A. Phytoremediation of soils polluted with crude petroleum oil using Bassia scoparia and its associated rhizosphere microorganisms. Int. Biodeterior. Biodegrad. 2015, 98, 113-120. [CrossRef]

15. Chehregani, A.; Noori, M.; Yazdi, H.L. Phytoremediation of heavy-metal-polluted soils: Screening for new accumulator plants in Angouran mine (Iran) and evaluation of removal ability. Ecotoxicol. Environ. Saf. 2009, 72, 1349-1353. [CrossRef]

16. Willscher, S.; Mirgorodsky, D.; Jablonski, L.; Ollivier, D.; Merten, D.; Büchel, G.; Wittig, J.; Werner, P. Field scale phytoremediation experiments on a heavy metal and uranium contaminated site, and further utilization of the plant residues. Hydrometallurgy 2013, 131-132, 46-53. [CrossRef]

17. Li, C.; Ji, X.; Luo, X. Phytoremediation of heavy metal pollution: A bibliometric and scientometric analysis from 1989 to 2018. Int. J. Environ. Res. Public Health 2019, 16, 4755. [CrossRef]

18. Hegazy, A.K.; Emam, M.H. Accumulation and Soil-to-Plant Transfer of Radionuclides in the Nile Delta Coastal Black Sand Habitats. Int. J. Phytoremediat. 2010, 13, 140-155. [CrossRef] [PubMed]

19. Antonkiewicz, J.; Jasiewicz, C. The use of plants accumulating heavy metals for detoxification of chemically polluted soils. Electron. J. Pol. Agric. Univ. 2002, 5, 121-143.

20. Hegazy, A.K. Phytomonitoring and management of tar piles on the Qatari coastal marshes, Arabian Gulf. Environ. Pollut. 1995, 90, 187-190. [CrossRef]

21. Maiti, S.K.; Jaiswal, S. Bioaccumulation and translocation of metals in the natural vegetation growing on fly ash lagoons: A field study from Santaldih thermal power plant, West Bengal, India. Environ. Monit. Assess. 2008, 136, 355-370. [CrossRef]

22. Ali, S.; Abbas, Z.; Rizwan, M.; Zaheer, I.; Yavaş, I.; Ünay, A.; Abdel Daim, M.; Bin-Jumah, M.; Hasanuzzaman, M.; Kalderis, D. Application of Floating Aquatic Plants in Phytoremediation of Heavy Metals Polluted Water: A Review. Sustainability 2020, 12, 1927. [CrossRef]

23. Oyuela Leguizamo, M.A.; Fernández Gómez, W.D.; Sarmiento, M.C.G. Native herbaceous plant species with potential use in phytoremediation of heavy metals, spotlight on wetlands-A review. Chemosphere 2017, 168, 1230-1247. [CrossRef] [PubMed]

24. Hegazy, A.; Lovett-Doust, J. Plant Ecology in the Middle East; Oxford University Press: Oxford, UK, 2016.

25. Humphries, M.M.; Studd, E.K.; Menzies, A.K.; Boutin, S. To everything there is a season: Summer-to-winter food webs and the functional traits of keystone species. Integr. Comp. Biol. 2017, 57, 961-976. [CrossRef] [PubMed]

26. Baeshen, M.N.; Al-Attas, S.G.; Ahmed, M.M.; Hanafy, A.A.-E.L.M.E.L.; Anwar, Y.; Alotibi, I.A.; Baeshen, N.A. The effect of Rhazya stricta aqueous leaves extract on MRSA genotypes in Jeddah province. Biotechnol. Biotechnol. Equip. 2016, 30, 368-374. [CrossRef]

27. Al-Farraj, A.S.; Al-Wabel, M.I.; Al-Shahrani, T.S.; El-Maghraby, S.E.; Al-Sewailem, M.A.S. Accumulation coefficient and translocation factor of heavy metals through Rhazya strictagrown in the mining area of Mahad AD’Dahab, Saudi Arabia. Waste Manag. Environ. V 2010, 140, 325-336.

28. Ghoneim, A.M.; Al-Zahrani, S.S.; El-Maghraby, S.E.; Al-Farraj, A.S. Heavy Metals Accumulation in Rhazya stricta L. Plant Growing on Industrial Wastewater of Riyadh City, Saudi Arabia. J. Appl. Sci. 2014, 14, 2007-2010. [CrossRef] 
29. Badr, N.; Al-Qahtani, K.M. Treatment of wastewater containing arsenic using Rhazya stricta as a new adsorbent. Environ. Monit. Assess. 2013, 185, 9669-9681. [CrossRef]

30. Badr, N.; Fawzy, M.; Al-Qahtani, K.M. Phytoremediation: An Ecological Solution to Heavy-Metal-Polluted Soil and Evaluation of Plant Removal Ability. World Appl. Sci. J. 2012, 16, 1292-1301.

31. Al-Qahtani, K. Assessment of heavy metals accumulation in native plant species from soils contaminated in riyadh city, saudi arabia. Life Sci. J. 2012, 9, 384-392.

32. Ibrahim, M.M.; Alsahli, A.A.; El-Gaaly, G. Evaluation of phytoremediation potential of six wild plants for metal in a site polluted by industrial wastes: A field study in Riyadh, Sudi Arabia. Pak. J. Bot. 2013, 42, 571-576.

33. Khattak, I.M.; Jabeen, R.; Hameed, M.; Arfat, Y. A study of some heavy metals found in medicinal plants (Euphorbia cornigera, Rhazya stricta and Citrullus colocynthis) in Turbat region of Balochistan with reference to prevention of environmental pollution. Pak. J. Bot. 2015, 47, 1511-1516.

34. Shah, A.; Niaz, A.; Ullah, N.; Rehman, A.; Akhlaq, M.; Zakir, M.; Khan, M.S. Comparative Study of Heavy Metals in Soil and Selected Medicinal Plants. J. Chem. 2013, 2013, 1-5. [CrossRef]

35. Helmisaari, H.S.; Salemaa, M.; Derome, J.; Kiikkila, O.; Uhlig, C.; Nieminen, T.M. Remediation of heavy metal-contaminated forest soil using recycled organic matter and native woody plants. J. Environ. Qual. 2007, 36, 1145-1153. [CrossRef]

36. Hameed, M.A.; Reid, J.B.; Rowe, R.N. Root confinement and its effects on the water relations, growth and assimilate partitioning of tomato (lycopersicon esculentum mill). Ann. Bot. 1987, 59, 685-692. [CrossRef]

37. Smical, A.-I.; Hotea, V.; Oros, V.; Juhasz, J.; Pop, E. Studies on transfer and bioaccumulation of heavy metals from soil into lettuce. Environ. Eng. Manag. J. 2008, 7, 609-615. [CrossRef]

38. Kimbrough, R.D.; Krouskas, C.A. Contribution of lead in soil to children's lead burden, an update. Chem. Speciat. Bioavailab. 2012, 24, 105-112. [CrossRef]

39. Soleimani, M.; Hajabbasi, M.A.; Afyuni, M.; Charkhabi, A.H.; Shariatmadari, H. Bioaccumulation of nickel and lead by Bermuda grass (Cynodon dactylon) and tall fescue (Festuca arundinacea) from two contaminated soils. Casp. J. Environ. Sci. 2009, 7, 59-70.

40. Ji-Tao, S.; Bao-guo, T.; Hong-tao, W.; Basta, N.; Schroder, J.; Casillas, M. Assessing availability, phytotoxicity and bioaccumulation of lead to ryegrass and millet based on $0.1 \mathrm{~mol} / \mathrm{L} \mathrm{ca}(\mathrm{NO} 3) 2$ extraction. J. Environ. Sci. 2006, 18, 958-963. [CrossRef]

41. Midrar-ul-Haq; Khattak, R.A.; Puno, H.K.; Saif, M.S.; Memon, K.S.; Sial, N.B. Bioaccumulation of trace elements by different plant species grown on potentially contaminated soils of nwfp, pakistan. Asian J. Plant Sci. 2005, 4, 383-387.

42. Gardea-Torresdey, J.L.; Peralta-Videa, J.R.; Montes, M.; de la Rosa, G.; Corral-Diaz, B. Bioaccumulation of cadmium, chromium and copper by Convolvulus arvensis L.: Impact on plant growth and uptake of nutritional elements. Bioresour. Technol. 2004, 92, 229-235. [CrossRef]

43. Rudani, K.; Patel, V.; Kalavati, P. The importance of zinc in plant growth-A review. Int. Res. J. Nat. Appl. Sci. 2018, 5, 38-48.

44. Mertens, J.; Smolders, E. Zinc. In Heavy Metals in Soils: Trace Metals and Metalloids in Soils and Their Bioavailability; Alloway, B.J., Ed.; Springer: Dordrecht, The Netherlands, 2013; pp. 465-493. [CrossRef]

45. Baker, A.J.M.; Brooks, R.R. Terrestrial higher plants which hyperaccumulate metallic elements a review of their distribution, ecology and phytochemistry. Biorecovery 1989, 1, 81-126.

46. Bert, V.; Macnair, M.; De Laguerie, P.; Saumitou-Laprade, P.; Petit, D. Zinc tolerance and accumulation in metallicolous and nonmetallicolous populations of Arabidopsis halleri (Brassicaceae). New Phytol. 2000, 146, 225-233. [CrossRef]

47. Tangahu, B.V.; Sheikh Abdullah, S.R.; Basri, H.; Idris, M.; Anuar, N.; Mukhlisin, M. A review on heavy metals (As, $\mathrm{Pb}$, and $\mathrm{Hg}$ ) uptake by plants through phytoremediation. Int. J. Chem. Eng. 2011, 2011, 939161. [CrossRef]

48. Plum, L.M.; Rink, L.; Haase, H. The essential toxin: Impact of zinc on human health. Int. J. Environ. Res. Public Health 2010, 7, 1342-1365. [CrossRef]

49. Oh, Y.J.; Kim, H.; Seo, S.H.; Hwang, B.G.; Chang, Y.S.; Lee, J.; Lee, D.W.; Sohn, E.J.; Lee, S.J.; Lee, Y.; et al. Cytochrome b5 Reductase 1 Triggers Serial Reactions that Lead to Iron Uptake in Plants. Mol. Plant 2016, 9 , 501-513. [CrossRef] 
50. Ali, H.; Khan, E.; Sajad, M.A. Phytoremediation of heavy metals: Concepts and applications. Chemosphere 2013, 91, 869-881. [CrossRef]

51. Bini, C.; Wahsha, M.; Fontana, S.; Maleci, L. Effects of heavy metals on morphological characteristics of Taraxacum officinale Web growing on mine soils in NE Italy. J. Geochem. Explor. 2012, 123, 101-108. [CrossRef]

52. Usman, K.; Al-Ghouti, M.A.; Abu-Dieyeh, M.H. The assessment of cadmium, chromium, copper, and nickel tolerance and bioaccumulation by shrub plant Tetraena qataranse. Sci Rep. 2019, 9, 5658. [CrossRef]

53. Wuana, R.; Okieimen, F.E. Heavy metals in contaminated soils: A review of sources, chemistry, risks and best available strategies for remediation. Int. Sch. Res. Netw. 2011, 2011,1-20. [CrossRef]

54. Jadia, C.D.; Fulekar, M. Phytoremediation of heavy metals: Recent techniques. Afr. J. Biotechnol. 2009, 8, 921-928.

55. Yoon, J.; Cao, X.; Zhou, Q.; Ma, L.Q. Accumulation of $\mathrm{Pb}, \mathrm{Cu}$, and $\mathrm{Zn}$ in native plants growing on a contaminated Florida site. Sci. Total Environ. 2006, 368, 456-464. [CrossRef] [PubMed]

56. Zhang, S.; Li, T.; Huang, H.; Zou, T.; Zhang, X.; Yu, H.; Zheng, Z.; Wang, Y. Cd accumulation and phytostabilization potential of dominant plants surrounding mining tailings. Environ. Sci. Pollut. Res. 2012, 19, 3879-3888. [CrossRef] [PubMed]

57. Hegazy, A.K.; Abdel-Ghani, N.T.; El-Chaghaby, G.A. Adsorption of phenol onto activated carbon from Rhazya stricta: Determination of the optimal experimental parameters using factorial design. Appl. Water Sci. 2014, 4, 273-281. [CrossRef]

58. Amin, H.; Arain, B.A.; Jahangir, T.M.; Abbasi, M.S.; Amin, F. Accumulation and distribution of lead (Pb) in plant tissues of guar (Cyamopsis tetragonoloba L.) and sesame (Sesamum indicum L.): Profitable phytoremediation with biofuel crops. Geol. Ecol. Landsc. 2018, 2, 51-60. [CrossRef]

59. Aragón, L.; Lasso, E. How do young cacti (seeds and seedlings) from tropical xeric environments cope with extended drought periods? J. Arid Environ. 2018, 154, 1-7.

60. Ruiz, M.A.; Golberg, A.; Molas, M.L. From seed to seedling: An ecophysiological point of view. In From Seed Germination to Young Plants: Ecology, Growth and Environmental Influences; Busso, C.A., Ed.; Nova Biomedical: New York, NY, USA, 2013; pp. 3-26.

61. Güleryüz, G.; Kırmızı, S.; Arslan, H.; Derya, S. The effects of heavy metals on the seed germination and seedling growth of two endemic verbascum species. Fresenius Environ. Bull. 2016, 25, 1134-1142.

62. Sethy, S.K.; Ghosh, S. Effect of heavy metals on germination of seeds. J. Nat. Sci. Biol. Med. 2013, 4, 272-275. [CrossRef]

63. Wang, H.; Zhong, G.; Shi, G.; Pan, F. Toxicity of Cu, Pb, and Zn on Seed Germination and Young Seedlings of Wheat (Triticum aestivum L.). In Proceedings of the Computer and Computing Technologies in Agriculture IV, Nanchang, China, 22-25 October 2010; pp. 231-240.

64. Wang, J.; Li, W.; Zhang, C.; Ke, S. Physiological responses and detoxific mechanisms to Pb, Zn, $\mathrm{Cu}$ and Cd in young seedlings of Paulownia fortunei. J. Environ. Sci. 2010, 22, 1916-1922. [CrossRef]

65. Bae, J.; Benoit, D.L.; Watson, A.K. Effect of heavy metals on seed germination and seedling growth of common ragweed and roadside ground cover legumes. Environ. Pollut. 2016, 213, 112-118. [CrossRef]

66. Abraham, K.; Sridevi, R.; Suresh, B.; Damodharam, T. Effect of heavy metals $(\mathrm{Cd}, \mathrm{Pb}, \mathrm{Cu})$ on seed germination of Arachis hypogeae L. Asian J. Plant Sci. Res. 2013, 3, 10-12.

67. Awofolu, O.R. A survey of trace metals in vegetation, soil and lower animal along some selected major roads in metropolitan city of Lagos. Environ. Monit. Assess. 2005, 105, 431-447. [CrossRef] [PubMed]

68. Zhuang, P.; Yang, Q.W.; Wang, H.B.; Shu, W.S. Phytoextraction of heavy metals by eight plant species in the field. Water Air Soil Pollut. 2007, 184, 235-242. [CrossRef]

69. Padmavathiamma, P.K.; Li, L.Y. Phytoremediation technology: Hyper-accumulation metals in plants. Water Air Soil Pollut. 2007, 184, 105-126. [CrossRef]

(C) 2020 by the authors. Licensee MDPI, Basel, Switzerland. This article is an open access article distributed under the terms and conditions of the Creative Commons Attribution (CC BY) license (http://creativecommons.org/licenses/by/4.0/). 